\title{
INFRALOCUS: CARTOGRAFIANDO LAS PRÁCTICAS DE INFRAHUMANIDAD DEL PASEO DE LA GUERRA CIVIL ${ }^{1}$
}

\author{
Infralocus, Sites of Infrahumanization: \\ Mapping the paseo during the Spanish Civil War
}

\author{
David Casado-Neira* \\ Universidade de Vigo
}

\begin{abstract}
Palabras clave
Desaparición

Franquismo

Paisaje

Cartografía

Infralocus nos. Estos infraloci no son únicamente el escenario de una muerte violenta, son paisajes del terror, lugares marginales que marcan a quien es alli muerto. En muchos casos se trata de enterramientos de carácter individual, que parecen más bien fosas comunes fragmentadas o fosas de tela de araña, con un ejecutor común y víctimas geográficamente dispersas. En este texto propongo una metodología peripatética para aproximarme a 14 lugares de muerte. Se rehúye de un enfoque basado en el testimonio con el objetivo de indagar en las otras dimensiones que surgen y están activas en torno al paseado más allá de la veracidad y la búsqueda de justicia o reparación.
\end{abstract}

\section{Keywords}

Disappearance

Francoism

Landscape

Mapping

Infralocus

ABSTRACT: Currently, the main point of the claims regarding the Spanish Civil War and the Franco's dictatorship repression is the location and exhumation of (mass) graves. In the Spanish Galician region (among others) the chosen location were common and frequented places, even if geographically there was a possible to use "chupaderos» or "black holes» to make the bodies disappear. The bodies were abandoned where they were visible. In this text a peripatetic methodology is proposed, approaching 14 places of death. The aim is to avoid a testimony based perspective, in order to go into other dimensions that arise beyond the search of veracity and justice or reparation. Disappearance practices deny the humanity of those who have been executed, the mortal remains lie in marginal places and in forms. Symbolically the killed person is not more considered a human, but a subhuman. These infraloci are not just the scenery of a violent death, they are landscapes of terror, marginal places marking the dead person. Even in cases of individual graves, it is possible to talk about mass graves, in this case, as fragmented common burials, or spider web graves, with same executor and victims geographically dispersed.
RESUMEN: La localización y exhumación de fosas comunes son actualmente, podemos decir, el foco de las reivindicaciones con respecto a la Guerra Civil española y la represión de la dictadura franquista. En territorios como Galicia, a pesar de haberse podido utilizar «chupaderos» o «agujeros negros" para desaparecer los cuerpos, se optó por lugares comunes y frecuentados a dónde se paseaba a los insurgentes. Los cuerpos eran abandonados allí donde eran visibles, haciendo que las prácticas de represión adquieran una dimensión pública inscrita en el espacio, que también es así violentado. Esas prácticas de desaparición niegan la humanidad de quien ha sido ajusticiado, los restos yacen en lugares y en formas marginales, se marcan simbólicamente como infrahuma-

1 Este artículo ha sido escrito en el marco de discusiones y trabajos colectivos del proyecto «Desapariciones. Estudio en perspectiva transnacional de una categoría para gestionar, habitar y analizar la catástrofe social y la pérdida» (CSO2015-66318-P). También agradezco a todos/as los y las participantes del Seminario internacional "Nuevas desapariciones, nuevos espacios» (celebrado en Bilbao en enero de 2019, bajo el auspicio de la Universidad del País Vasco), quienes me han discutido, comentado y cuestionado, y me han llevado a la versión actual de este texto.

* Correspondencia a / Correspondence to: David Casado-Neira. Universidade de Vigo. Fac. Ciencias da Educación (32004 Ourense). - dcneira@uvigo.es - http:// orcid.org/0000-0003-3521-5039.

Cómo citar / How to cite: Casado-Neira, David (2020). Infralocus: cartografiando las prácticas de infrahumanidad del paseo de la Guerra Civil. Papeles del CEIC, vol. 2020/1, papel 226, 1-24. (http://dx.doi.org/10.1387/pceic.20883).

Recibido: mayo, 2019; aceptado: noviembre, 2019.

ISSN 1695-6494 / ㄷ 2020 UPV/EHU 


\section{INTRODUCCIÓN}

La Guerra Civil española (1936-1939), que desembocó en la dictadura franquista (1939-1975), ha marcado la agenda política del país hasta la actualidad, y no solo en la manera en la que se ha llevado a cabo la transición democrática, sino también en las políticas del recuerdo y del olvido de vencedores y vencidos, y en las narrativas sobre responsabilidades y culpas entre ambos bandos. Un eje relevante de las reivindicaciones actuales con respecto a la Guerra Civil y la represión de la dictadura franquista es la localización y exhumación de fosas. El franquismo sí se ocupó de sus muertos, sus fosas han sido abiertas, las muertes certificadas y prácticas memorialísticas llevadas a cabo (Rodrigo, 2008: 199-213; Prada, 2011: 36). En el caso de las muertes republicanas aún no se ha culminado este proceso, llevando la represión al terreno del olvido posterior y la desmemorialización. Se ha llevado a cabo un dispar reconocimiento de las víctimas desde las instancias oficiales: las del bando franquista han ido ocupando nombres de calles, muros de iglesias y monumentos públicos desde el mismo momento de la contienda, y las del bando republicano han permanecido silenciadas hasta fechas recientes (y sólo gracias a iniciativas de asociaciones, administraciones locales especialmente comprometidas con la memoria republicana y particulares). La de las víctimas del bando sublevado se fue certificando como una forma de dolor y sufrimiento humano hegemónico, heroico y público, y la otra marginal, de resistencia y privado, abocada a habitar los paisajes inciertos del terror amenazante.

Aunque la represión del franquismo haya sido de diversa índole, hay una práctica característica y que ha venido a ocupar el lugar predominante en las narrativas de la represión: la figura del "paseado», que ha englobado las prácticas de desaparición durante el franquismo. En las sacas y los paseos se iba a buscar a las personas a sus casas o lugares de trabajo de los que eran literalmente llevadas con la excusa de acudir ante una autoridad, o podía hacerse con personas ya retenidas en centros de detención o capturadas en un enfrentamiento armado. El paseo consistía en una forma de arrancar a la persona fuera de un espacio que podía ofrecer algún tipo de protección; es, por lo tanto, una práctica de deslocalización que permitía la impunidad. Estas prácticas no tienen únicamente consecuencias jurídicas, ya que en estos escenarios de incertidumbre se generan imaginarios -en el sentido que les atribuye Castoriadis (1975) - de mala muerte, por cómo murieron ("a sangre y fuego») y cómo fueron tratados los cuerpos. Los lugares de paseo y ejecución responden a muertes que se construyen sobre narrativas de derrota, humillación y ensañamiento.

El espacio opera, en este caso, como un dispositivo que vendría a demostrar o no y a definir la naturaleza no humana de estos individuos. Ahí se constituye lo infrahumano. No se corresponde a la diferencia entre los infra- y los superhombres de la que nos habla Giorgio Agamben (2000: 11), sino que se trata de procesos de lo que, por un lado, se considera netamente humano en base a las vidas con valor - retomando la tesis de Judith Butler «lo que cuenta como humano, y finalmente, lo que hace que una vida valga la pena» (2006: 46) -; y, por otro lado, deshumanizantes, lo que es común a muchas prácticas represivas, entre otras, en los genocidios (Burucúa y Kwiatkowski, 2014). Es una práctica que puede alcanzar una gradación diversa entre lo humano, lo no humano, y lo animal; de ahí la oportunidad del concepto de infrahumanidad, como justificación de la eliminación de vidas que no merecen la pena ser vividas.

La degradación humana se expresa ya así en el pensamiento conservador antirrepublicano prebélico de ciertas élites intelectuales, como es en el caso del psiquiatra de referencia del 
franquismo Antonio Vallejo-Nájera, quien en la revista de corte católico-monárquica Acción Española (publicada entre 1931 y 1936) popularizaba la idea del infrahumano: "En el individuo infrahumano marcan el carácter los instintos, que, estimulados por el temperamento, le llevan a una conducta animal y de satisfacción de todos los apetitos» (1936: 179), como caracterizaría a "los marxistas» quienes se encuentran lejos de:

"[l]a verdadera raza española [que] es la hispano-romano-gótica, proveniente de tres troncos raciales: el ibérico, el latino y el gótico, empero fusionados los referidos troncos antropológicos por la consistente amalgama del pensamiento católico [...] que nos fusiona en Dios, en España y en el Caudillo.» (1938: 16).

Además, su infrahumanidad se demuestra en las condiciones y lugares que dan fe de ello, los lugares operan como dispositivos de la represión. Esto tiene su correspondencia espacial. Los espacios de la represión son los lugares de enterramiento, los del abandono de los cadáveres de las personas ejecutadas, también los de las ejecuciones: muelles, puentes, tapias de cementerios, playas, simas, cunetas, caminos, montes y otros (Nomes e Voces, 2016; Etxeberria, Serrulla y Herrasti, 2014) - de la misma manera que también las fosas comunes constituyen formas de enterramiento infrahumano (Ferrándiz, 2009: 86-87)-. Las localizaciones son liminales, marcan el estar fuera de lo social normativo, lo hegemónico, lo decente y bienpensante. No se trata de lugares que adquirieran su condición por ser escenario de las ejecuciones, eran lugares comunes, pero que ya enmarcaban prácticas previas al filo de lo social: muros traseros de cementerios (en extramuros de la muerte digna), cunetas (al borde de la lo transitable), descampados (los terrenos baldios e improductivos), etc.

Partiendo de su definición geométrica, un locus es una posición en un espacio, pero no definida por puntos o coordinadas fijas, sino por su relación entre otros puntos; un sistema de puntos que cumplen una o varias condiciones (James y James, 1992: 255). En una apropiación del concepto derivándolo hacia lo social no nos referimos, en consecuencia, a ubicaciones geográficas precisas, sino a lugares que adquieren una determinada significación, una carga simbólica o que responden a determinados imaginarios. Es lo que denomino como infralocus, un lugar que no es solo una localización, escenario o testigo geográfico, es también usado como instrumento de las prácticas de infrahumanización, ligadas a las de muerte. No son ubicaciones ostensibles ni clandestinas, como nos podemos encontrar en el Lager del III Reich o en el Centro Clandestino de Detención de la dictadura argentina 1976-1983 (Sturdy Colls, 2015; Calveiro, 1998); tampoco se trata de un ejercicio sistemático de eliminación de poblaciones, pero sí de limpieza política. Se trata aquí de una sistematicidad de paralización y sometimiento de la población en general ante un nuevo orden político, económico, moral y cultural.

En el caso español, nos encontramos con lugares en los que el conflicto armado entre ambos bandos se prolonga (el caso de Madrid, Valencia, Barcelona), mientras que en otros (como en Galicia o Navarra) la victoria de las fuerzas sublevadas es rápida, y en donde se lleva desde el inicio de la contienda una práctica de represión difusa, persistente y moralizante. En Galicia, lugar de este trabajo, las prácticas de represión presentan unas características que nos permiten acercarnos a la lógica de la represión como una forma de dominio del espacio a través de la violencia simbólica. La rápida victoria de los sublevados aquí ha supuesto la ausencia de grandes frentes de batalla y enfrentamientos, con la excepción de los choques entre Guardia Civil y maquis y huidos, más en una lógica de guerrilla. Por el contrario, hubo una práctica, intensa y extensa, programada de eliminación focalizada (podríamos decir quirúrgica) de de- 
terminadas personas implicadas de forma activa en el gobierno e ideario afín a la Segunda República. No nos encontramos aquí grandes fosas (con la excepción de la de Aranga con 37 casos), sino multiplicidad de muertes en lugares comunes o fosas de uno o dos cuerpos como nos muestran los estudios de la geografía de la represión en el lugar (Juana, Rodriguez y Prada, 2005; Prada, 2006, 2011; Gómez Bravo, 2017). No se trata de un fenómeno exclusivo en Galicia, pero sí nos permite acceder a un caso en el que abordar y entender esas prácticas de represión selectivas durante la contienda civil y el franquismo, que dará lugar a una guerra, primero, y a un gobierno del terror, después.

No es mi intención demostrar aquí una especificidad gallega, sino acercarme sobre un terreno concreto y con características comunes que permita un enfoque contextualizado. Sí es cierto que hay unas características que lo diferencian de otros territorios: un gran peso de la agricultura a pequeña escala muy pragmática (y con gran peso de las interrelaciones de vecindad), una gran fragmentación de la propiedad de la tierra, un tejido industrial de peso reducido, un poder caciquil activo, un sindicalismo agricola, marinero e industrial en emergencia y un proceso de modernización incipiente (Prada, 2014), todo en un medio altamente humanizado y agreste. No podemos olvidar también que Galicia había aprobado el 28 de junio de 1936 su Estatuto de autonomía lo que lo situaba en la mira de los salvaguardas de la unidad de España.

Galicia presenta más de $1.500 \mathrm{~km}$ de costa atlántica, numerosos cauces fluviales que atraviesan el territorio y una zona montañosa con abundantes zonas abruptas y zonas de vegetación densas. La pregunta que se plantea es por qué habiendo la posibilidad geográfica de usar esos "chupaderos» o "agujeros negros de cuerpos», se haya optado por lugares comu$n^{2}{ }^{2}$. Los cuerpos eran abandonados alli donde eran visibles; y una vez descubiertos, las familias podían ser avisadas (o no) y los cadáveres levantados por la autoridad judicial. Siendo enterrados en emplazamientos atípicos (fosas comunes, extramuros en los cementerios...), casi siempre en secreto o discretamente, a veces por familiares, otras por alguien de la vecindad, voluntariamente $u$ obligados por las milicias.

La implantación de un régimen de terror continuo tenía como objetivo desactivar cualquier iniciativa de rebeldía o simple apoyo a los sublevados ${ }^{3}$. Los lugares escenario de estas prácticas respondian una misma lógica. Puentes, simas, cunetas, muros exteriores de cementerios, playas y cunetas no habrian sido lugares de muerte aleatorios o elegidos por su adecuación funcional, sino fundamentalmente por su valor simbólico, como parte de una práctica de infrahumanización (próxima a la animalización) del enemigo, con atribuciones que ya los situaban en la liminalidad social (van Gennep, 2008), las ejecuciones y abandono de cadáveres demandan lugares que enfaticen esa infrahumanidad, en el espacio social cotidiano. Lugares de

2 De las 3.659 víctimas con resultado de muerte documentadas entre los años 1936 y 1940, 6 (0,164\%) corresponden a fondeos en el mar, 55 (1,503\%) aparecen en playas o en sus inmediaciones, y en orillas de ríos, 14 (0,383\%), según datos de Nomes e Voces (2016).

3 Tengamos aquí en cuenta que Galicia, en primer lugar, comparte una frontera montañosa con Asturias y León, en donde sí hubo una mayor resistencia armada a la sublevación, y había que evitar que del lado gallego llegasen apoyos al bando republicano o que fuese posible establecer vías de comunicación o salida a través del mar a América o Europa, o por tierra con Portugal. En segundo lugar, la propia estructura social, basada en redes familiares y de vecindad con una base agrícola sin grandes propietarios de tierra hacía muy difícil percibir una clara frontera entre amigos y enemigos. Y que, finalmente, se trata de un territorio abrupto, con muchas áreas aisladas, de difícil acceso y con comunicaciones limitadas que debían de poder ser controladas con medios reducidos. Estos tres elementos justifican el recurso a una forma de represión geolocalizada persistente (continua y duradera), de alto impacto simbólico y deslocalizada. 
los que se hablaba a media voz, lugares que se evitaban, lugares de lo residual, que entroncan con la práctica del concealment, no un mero abandono, sino un encubrimiento programado (Anstett, 2017: 42-44) que responde a una intencionalidad represiva.

\section{PASEANDO POR LOS LUGARES}

El interés por el testimonio en casos de desapariciones (y asimilados) ha sido central, así como la búsqueda de indicios, rastros y pruebas. En el presente el testimonio "se ha convertido en la forma canónica de la palabra de las víctimas» (Martínez, Robles y Ruiz-Estramil, 2019: 175), pero que no agota las posibilidades de indagar más allá de la construcción de una verdad. Es más, la búsqueda de respuestas (y preguntas) no se puede restringir a una forma canónica derivada de la legitimación emocional del testimonio de supervivientes, en dónde este se convierte en la prueba central (Wieviorka, 1998), sino que puede -y debe- encontrarse más allá de lo oral (o sus formas de registro):

«Si la ausencia es una característica definitoria de la desaparición, las materialidades singulares que dejan a su paso son tanto testimonio de ese borrado violento como testimonio y vía posible - siempre irrealizable plenamente-, de regreso o conexión con la persona desaparecida.» (Casado-Neira et al., 2019: 241).

No es casual pues que el campo de las desapariciones sea terreno de diversos conocimientos forenses (médico, arqueológico, geológico...) que permitan demostrar lo ocurrido. Se puede afirmar que se ha desarrollado un enfoque centrado en la búsqueda de respuestas, en donde la veracidad es central ${ }^{4}$. De la misma manera ha ocurrido en el caso español, donde la posibilidad de acceder a testimonios de primera mano es cada vez más limitada dada la lejanía de los hechos, aunque se ha ido llevando a cabo ya desde el primer exilio (en 1937) un trabajo de registro de testimonios que se ha intensificado en el último decenio. Parece que se han dado dos supuestos por inevitables: primero, que la única forma de acercarnos al campo de las víctimas es a través de testimonios - siempre que estos sean verídicos-; segundo, que condición de víctima es, en última instancia, una cuestión de identificación (forense). Desde nuestras disciplinas (la sociología, en concreto, y las sociales, por extensión) no nos podemos dar por satisfechos con estas respuestas que únicamente atienden a una posibilidad de enunciar lo ocurrido como verdad (el testimonio) y asumen una objetividad técnica (la médicoforense). Se trata de definitiva de un cierre en falso $y$, en consecuencia, de un debate abierto en nuestras disciplinas en las que se produce una fractura de la tríada epistemología-metodología-técnica como destacan Gatti, Martínez y Peñaranda-Cólera en la investigación sobre desaparición:

"Y sin embargo, estos asertos, aunque tienen traducción ética, estética o metodológica, no tienen traducción técnica: se centran en el qué, pero poco sobre el cómo, con qué o desde dónde; se constata el problema para acercarse a un objeto de este tipo, pero falta la sistematización de la mirada técnica, a veces por resignación respecto a la imposibilidad de representar lo irrepresentable; otras porque se huye

\footnotetext{
4 Un ejemplo de un análisis que rompe con el enfoque testimonial y probatorio a favor de uno narrativo lo tene-
} mos en Gatti (2008). 
hacia otros campos o disciplinas, con procedimientos que permitirían de alguna forma representar la desaparición, como ocurre con la fotografía o con el arte. O, lo más común, adoptar soluciones técnicas ya conocidas, como las entrevistas, los grupos de discusión, la observación participante, el análisis del discurso...» (2019: 255).

Me aproximo a 14 destinos urbanos y rurales bajo una premisa centrada en la dimensión espacial como escenario ${ }^{5}$. Se trata de lugares geográficamente irrelevantes y anodinos, casi siempre próximos a las poblaciones de las que provenían las personas paseadas. Parte del traslado de quien fue ejecutado se hizo a pie o en camión. Son lugares que, en la mayor parte de los casos, carecen de cualquier tipo de identificación posible; en otros se ha procedido a iniciativas de memorialización.

Se procedió en un primer momento a un proceso de identificación de los destinos, documentación in situ con cartografización, descripción, registro de imagen y audio. Las similitudes y/o disimilitudes entre espacios de muerte no tiene la intención de buscar o descubrir parámetros o principios básicos comunes; se pretende detectar indicios de lo que permanece, de lo que podría ser cierta banalidad topológica y simbólica.

Presento una serie de visitas en forma de paseo y deambulaciones andando por los lugares y sus proximidades. No busco informantes, solo lo que capto en el momento y de quien se dirige a mí. Documento fotográfica y sonoramente los lugares. Llego, estoy, deambulo y permanezco, después me voy. Esto se complementa con un trabajo básico de documentación. Muchas son las ventanas que se abren y los hilos de los que habrá que seguir tirando. No se trata de una etnografía heroica, sino de la aparente banalidad, en la que no hay tanto búsquedas como encuentros (con personas, objetos, animales...). No se entiende como una metodología exclusiva para poder abordar semejantes realidades, sino una forma de explorar otros acercamientos al terreno, dejarme arrastrar por lo experimentado, y después analizar, como las prospecciones previas en arqueología. ¿Qué mejor manera de estudiar un espacio que estar y caminar por él? Recordando las palabras de Robert Walser en su alegato a favor del paseo:

«El señor director o señor tasador dijo:

- iPero siempre se le ve paseando!

- Pasear - respondi yo- me es imprescindible, para animarme y para mantener el contacto con el mundo vivo, sin cuyas sensaciones no podría escribir media letra más ni producir el más leve poema en verso o prosa. Sin pasear estaría muerto, y mi profesión, a la que amo apasionadamente, estaría aniquilada. Sin pasear y recibir informes no podría tampoco rendir informe alguno ni redactar el más mínimo artículo, y no digamos toda una novela corta. Sin pasear no podría hacer observaciones ni estudios. Un hombre tan inteligente y despierto como usted podrá entender y entenderá esto al instante." (2001:52).

El visitar los lugares como práctica peripatética permite abrir las posibilidades de la mirada descentrada, periférica y ampliar las posibilidades de conocimiento, como la define el arquitecto Juhani Pallasmaa:

5 Para la selección de los lugares retomamos la nomenclatura usada en el proyecto Nome e Voces (2016) realizado entre los años 2007 y 2012, y que constituye hasta la fecha la base de datos disponible más completa y contrastada sobre víctimas del franquismo en Galicia. 
«Liberado del deseo implícito de control y poder del ojo, quizá sea precisamente en la visión desenfocada de nuestro tiempo cuando el ojo será capaz de nuevo de abrir nuevos campos de visión y pensamiento. La pérdida de foco ocasionada por la corriente de imágenes puede emancipar al ojo de su dominio patriarcal y dar lugar a una mirada participativa y empática.» (2014: 41).

Es una forma de percepción amplia de la realidad, en la que se abren otras formas de percepción que las netamente intelectuales, más allá de la búsqueda de elementos concretos.

El paseo no científico de Walser (2001) (pero si revelador) es una forma de estar y ver que se puede plasmar en una propuesta fenomenológica aplicable no solo a paisajes (escenarios), sino a espacios irrelevantes, comunes, cotidianos, anodinos, disimulados o ocultos:

«Hay múltiples vías y metodologías para aprender a experimentar en toda su plenitud esta contemplación, en especial cuando se aplica al paisaje. Una de ellas es la fenomenológica. Una fenomenología del paisaje nos facilita la comprensión del carácter de un lugar: este nos es revelado a través de diversos mecanismos y metodologías [...].» (Nogué, 2015: 145).

La metodología propuesta se basa en la presencia en el paisaje más allá de la mera observación guiado por una experiencia más compleja (aunque en las notas aquí presentadas nos ajustaremos a un enfoque netamente descriptivo para evitar suspicacias). El paseo permite una sensibilidad general $y$, en concreto, una mirada desfocalizada sobre un medio rico en significados y sentidos no desvelables con una mera descripción. No pretende substituir los métodos convencionales, mas investigar en vías que permitan captar más u otros sentidos del lugar —en la línea que propone el geógrafo André-Louis Sanguin (1981)—, más aún dada la centralidad de la dimensión espacial en la desaparición (Schindel y Colombo, 2014). De la misma manera, el arquitecto y urbanista, Francesco Careri, formaliza el "arte del encuentro» (2016: 35) como una metodología - la del caminar y la del detenerse-que nos permite conocer el espacio de una forma humana, o en la que lo humano es relevante.

La mía no es una búsqueda de pruebas forenses, me interesa ponerme en la perspectiva del lego que abarca con su mirada el entorno, no recurrir a herramientas de exploración del terreno, cartografiar y sacar a la luz esos lugares (eso es otra investigación y otros enfoques que aún me quedan por abordar). Me voy a minimizar, situarme como un caminante que ve desde su altura el entorno, a través de la simple vista, de la manera en la que es posible una movilidad en espacios de más difícil acceso, a pie. A la manera del flâneur (Benjamin, 1993) abierto al mundo, intentando tener una visión más pausada, menos focalizada en el destino y abrirme a lo que define esa ecología de la desaparición.

Recurro al "andar como práctica estética» (Careri, 2014). No es, así, la actual una herramienta que parta de nuevos presupuestos ni ajena a la tradición científica occidental. Ya en el siglo XIX, Alexander von Humboldt (2004), uno de los fundadores de la ciencias naturales y ecología modernas sustentó todo su trabajo de observación naturalista en la practica peripatética a través de la observación (y documentación) in situ, lo que le permitió ir más allá de los trabajos de sistematización linneanos y descubrir las conexiones no explícitas entre plantas y geografía (Lubrich y Möhl, 2019). Aunque, evidentemente, de dimensión radicalmente diferente en todos los sentidos a la del gran descubridor y pensador, mi intención es acercarme a los lugares desde una perspectiva más pausada que me permita comprender mejor las características del terreno en su configuración y usos; y explorar una forma de tra- 
bajo que permita aproximarnos de forma sistemática a terrenos y hechos marcados por la incertidumbre.

\section{LUGARES LIMINALES: LA DIDÁCTICA DEL ESPACIO}

El hecho de que gran parte de las prácticas represivas hayan sido llevadas a cabo por personas territorialmente próximas (Guardia Civil de los propios pueblos, grupos fascistas locales, responsables militares y políticos del lugar, vecinos, o sin arraigo pero con apoyo local) implica un conocimiento ya no solo del territorio en sus aspectos físicos, sino también de la relevancia y sus usos en las prácticas sociales comunes y habituales. Parece difícil pensar en la elección casual de esos locus, de la misma manera que no hay casualidad en que los cadáveres no acaben delante de una iglesia, a las puertas de los juzgados o delante de la casa del representante político de los sublevados.

La intencionalidad didáctica y moralizante (aleccionadora) de la represión se lleva a cabo también de forma espacial (Rodrigo, 2008: 38; Prada, 2011: 198) al responder a una práctica en la que use escogían con cuidado los lugares donde abandonar los cadáveres, junto a cruces de caminos o cerca de los puentes, para que el terror tuviera el mayor impacto posible» (Preston, 2011: 296). Se trata de lugares en los que se ha procedido a la construcción una determinada representación, una escena. Se le da forma visual a una intencionalidad sobre un espacio, con unos actores (víctimas y victimarios) y destinado a un público. Hay lugares que están protegidos por su valor y carácter normalizador, otros que pueden ser elegidos de forma concreta o que se ajustan a las caracteristicas de un infralocus: ser visible, pero liminal y estar contaminado.

El uso de términos como el de subtierro - «un tipo de éxodo bajo tierra, quizá a una forma extrema de exilio interior, cuyo origen histórico sería el mismo que el de los exiliados, desterrados o transterrados que tuvieron que abandonar España» (Ferrándiz, 2011: 526)—implica un elemento "bajo tierra" claro que es la fosa. En el presente trabajo nos ocuparemos de lugares de muerte (no estrictamente de fosas) y de lugares que no esperan a salir a la luz, por lo que el componente "bajo tierra» adquiere una dimensión diferente. De sus condiciones de producción e historia social, política, simbólica y judicial, aqui son relevantes las simbólicas. En otras palabras, el infralocus correspondería a la carga simbólica del subtierro. Nos referimos a la manera de construir un escenario de violencia, no al lugar de una posible fosa. Es esa escenificación en donde los infraloci cobran sentido, porque marcan las muertes.

Ilustrémoslo con cinco ejemplos. Se trata de cinco localizaciones en cinco ayuntamientos diferentes que responden a formas de represión diferentes también. Es preciso indicar que con la excepción del primer caso - cueva Arcoia- no es posible establecer el lugar preciso de la muerte y enterramiento, solamente podemos establecer un área aproximada. Tres apuntes de orden metodológico: (i) las coordinadas geográficas incluidas corresponden al lugar documentado fotográficamente a modo contextual en su situación actual; (ii) se acompaña de un mapa histórico para reflejar la proximidad de núcleos de población y vías de comunicación ${ }^{6}$;

6 Todos los mapas históricos son mapas topográficos elaboradas por el Instituto Geográfico Nacional (CNIG, 2019) con una escala de 1:50.000 (la más detallada hasta el momento) realizados entre 1915 y 1960; se indica el año de realización y el número de hoja correspondiente. Se trata de minutas, mapas manuscritos de trabajos 
y (iii) una ortofoto que permite ilustrar el uso del territorio en esa época, concretamente en lo referente a núcleos urbanos, terrenos de cultivo (marcados por las parcelas amuralladas), zonas de pasto y vías de comunicación de uso en la época?

\subsection{Caso 1: Cueva Arcoia}

Ayuntamiento: Folgoso do Caurel. Coordinadas: 42.612778, -7.084166. Hoja topográfica: 157 (año 1947). Uso: Agrario (pastos, abandonados parcialmente en la actualidad).

Causa de muerte: enfrentamiento armado (causa probable) (2 personas). No está registrado en la base de datos de Nomes e Voces (2006).

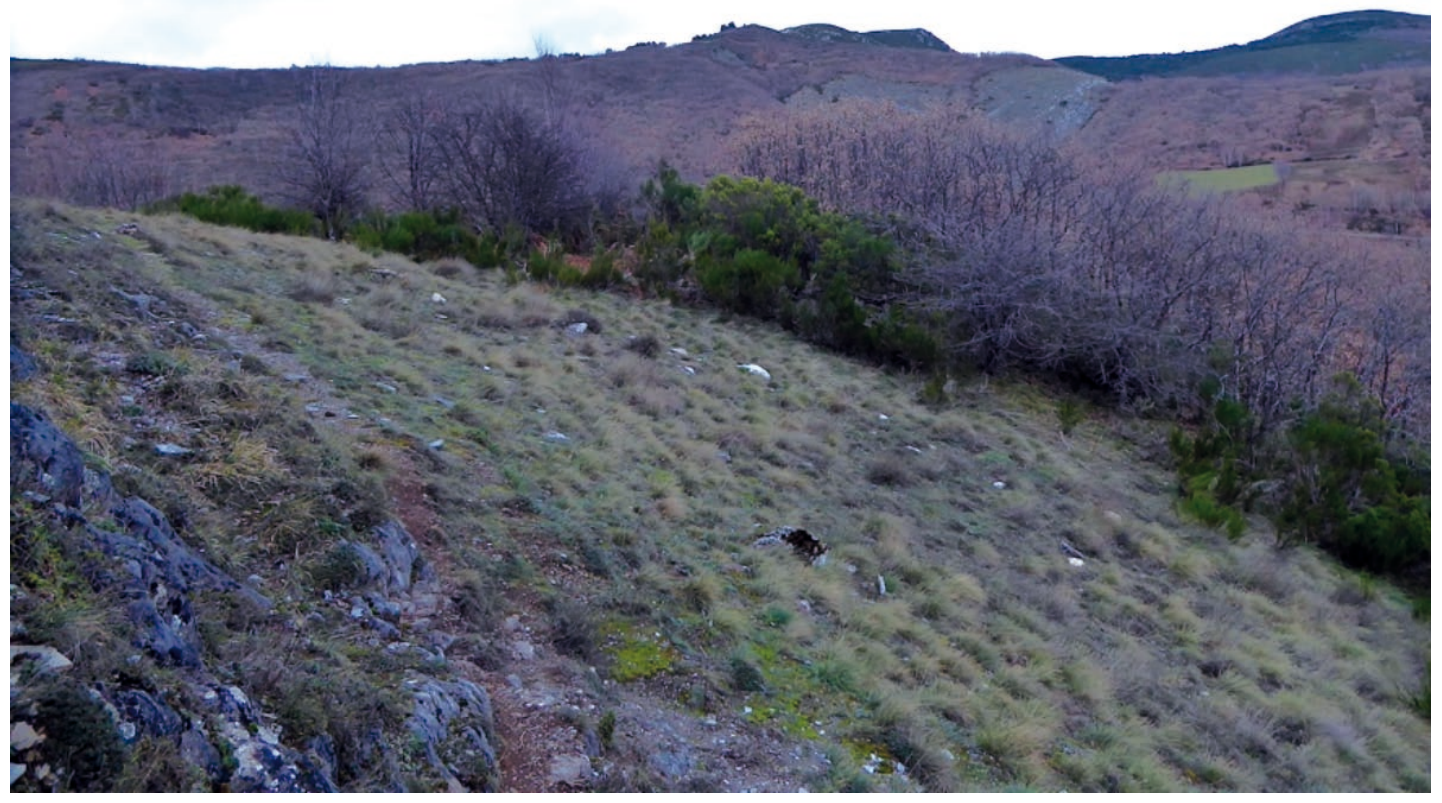

Imagen 1

Vistas desde la entrada de la cueva

(fotografía del autor)

previos a la publicación de la cartografía final (que en muchos casos saldrían a la luz décadas después). Las cartografías aqui presentadas corresponden al período 1940-1947 por lo que tampoco reflejan el momento inicial del conflicto (en 1936) pero considero bastante razonable asumir que en esos momentos no se produce una gran alteración del territorio (a diferencia de lo que pasaría a partir de la década de los 70 en todo el país por las transformaciones derivadas de los cambios económicos y productivas).

7 Las ortofotos corresponden a los vuelos fotogramétricos del denominado Vuelo Americano Serie A (escala 1/32.000) llevado a cabo por Army Map Service de los EE.UU. entre 1945 y 1946. Fuente cartográfica: IGN y CNIG (2019). Licencia de la cartografía: CC-BY 4.0. 
El primer caso es el más atípico, y precisamente por eso cabe destacarlo. Me encuentro en la montaña gallega, en una zona de amplias cumbres de monte bajo y profundos valles de frondosas. Lo que hoy es un paraje que podría parecer desolado ha sido un terreno de pastos y cultivos de cereal; testimonio de ello son los muros de piedra de las antiguas fincas en muchos casos ya ocultos por la maleza. Cerca de una cumbre se encuentra la cueva Arcoia (imagen 1), ubicada en la aldea de Céramo. Es una cueva ubicada hoy en un paraje recóndito, en los años 30 las aldeas se extendían a lo largo de un valle en el que abundaron los terrenos de cultivo y pastos extensivos, aunque ciertamente se trata de núcleos muy pequeños. Eran parajes aislados hacia el exterior, pero situados estratégicamente en las cercanías montañosas de la frontera con León. Hoy se encuentran en un proceso muy avanzado de despoblación.

Se trata de una cueva con interés espeleológico en la que no hay ninguna indicación de haber albergado restos humanos. En las inmediaciones de la cumbre a más de 1.300 metros de altitud, se accede a la entrada de la cueva sobre un paisaje de cumbres redondeadas por la erosión, y de vegetación baja (retamas, tojos, brezos y carquesas). Con el viento, siempre el viento que nos acompaña y ensancha la soledad de la cumbre. Parece difícil imaginarse a nadie ajeno a la zona andando por estas alturas, solo huido o de paso evitando las aldeas. No es un lugar de paso casual o habitual, ni con buenas vías de acceso.

Alli se han hallado restos humanos que podrian corresponder muy posiblemente a víctimas de la Guerra Civil, aunque no se ha podido demostrar de forma definitiva a partir de los análisis forenses. Se trata de dos personas, una entre 25-30 años y la segunda entre 10-14; el adulto con un traumatismo craneal y el menor con impacto de bala en la cabeza. Aunque se encuentran armas de la época franquista, podría tratarse de muertes de la Segunda Guerra Carlista (1872-1876). Los indicios hacia la Guerra Civil vendrían de la vaina de munición encontrada que fue de uso común en ese momento (Etxeberria, Serrulla y Herrasti, 2014: 276278).

Tampoco hay constancia de enfrentamientos armados en la época. De tratarse de un caso de la Guerra Civil sería el único del que habría algún tipo de constancia en sima o cueva en territorio gallego, y a pesar de las dudas sobre la cronología de los restos considero que merece la pena incluir la única referencia forense documentada sobre restos en una sima. Su valor aquí está en su carácter anómalo, y en la cuestión abierta sobre el origen de esos dos cuerpos baleados. La dificultad de acceso podría apuntar precisamente a la hipótesis de una falsa atribución a muertes de la represión franquista. Hoy la cueva se encuentra en peligro de deterioro por las visitas incontroladas, siendo en la actualidad un destino de turismo de aventuras sin referencias históricas ${ }^{8}$, y está pendiente la restricción de acceso al público (Albo, 2018).

8 Como se indica en una publicidad de visitas: «La cueva de Arcoia quizás sea la cueva más bonita y rica de Galicia en cuestión de formaciones. Descubrirás y admirarás impresionantes estalactitas y estalagmitas, formadas a lo largo de miles de años, por precipitación de los minerales contenidos en las aguas subterráneas que se filtran, muy despacio, a través del techo de la cueva. Esta cueva tiene gateras y trepadas fáciles y se encuentra a 20 min andando desde donde te deja el coche, entrando y saliendo por el mismo sitio. Normalmente no suele tener agua. Disfrutarás cuando trepes, te arrastres, camines agachado... En todo momento te acompañarán nuestros guías especializados» (Aventuras en Galicia 2019, negrita en el original). 

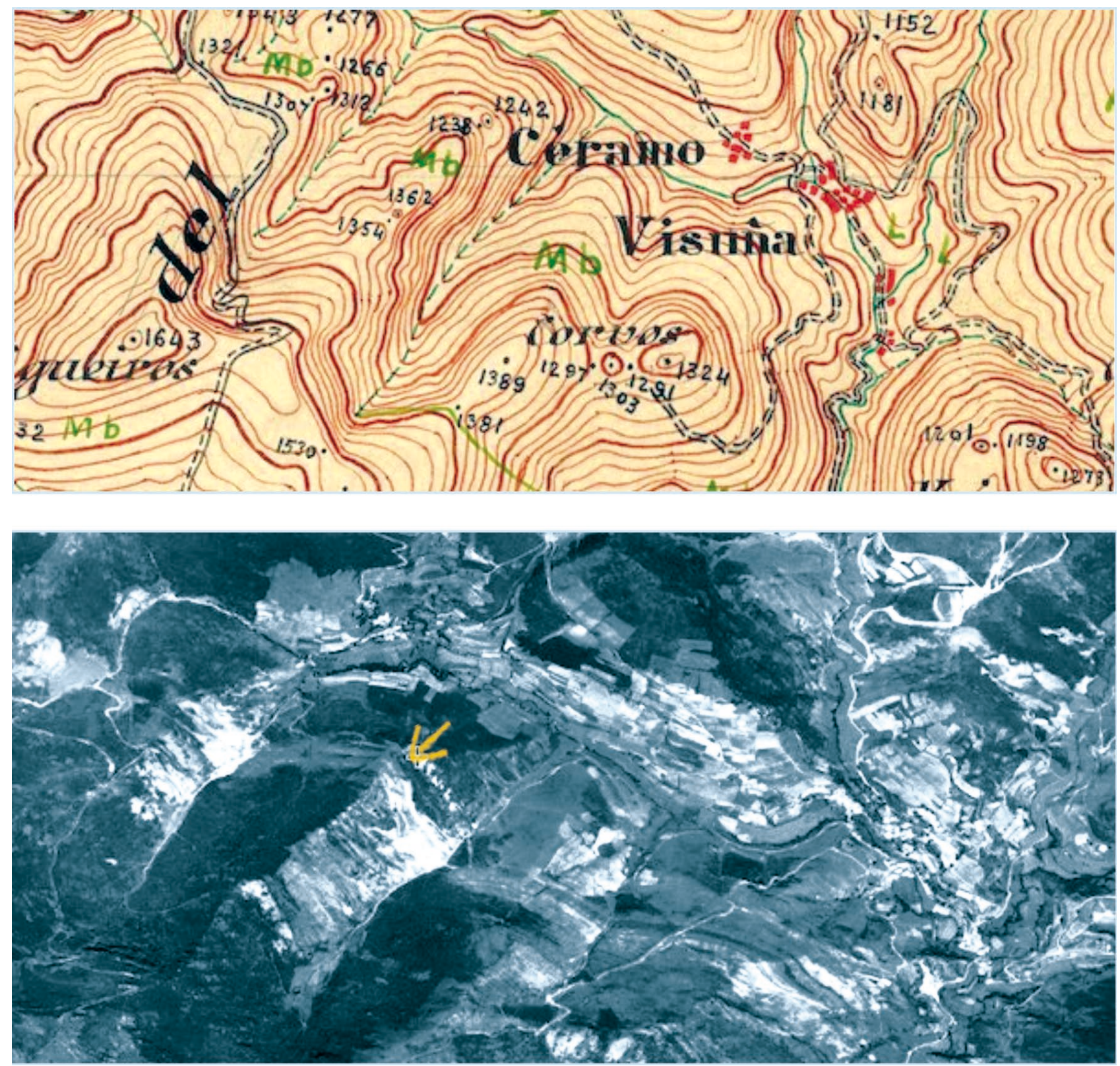

Imágenes 2 y 3

Mapa histórico. Ortofoto 9

9 Accesible en: http://www.ign.es/web/comparador_pnoa/index.html\#map=15/-788633.14/5253745.88/0/5/ amsb. Última visita: 04/12/2019. 


\subsection{Caso 2: Cementerio y río en Filgueira}

Ayuntamiento: Crecente. Coord: 42.212444, -8.197201. Hojas: 224 y 225 (1942). Uso: Agrario (abandonados parcialmente en la actualidad).

Causa de muerte: operación de castigo y limpieza (causa probable) sin identificar (2) -enterrados en la entrada del cementerio; también se descubre un cuerpo sin poder determinar si se trata de una víctima de la Guerra Civil.

Filgueira era una antigua aldea con una alta densidad de población y actividad productiva, especialmente relativa a la industria maderera, agrícola intensiva y pesquerías, con una conexión por barca con el ayuntamiento de Cortegada, al otro lado del río Miño. Se trataba por lo tanto de un núcleo de tránsito habitual, en el camino entre Ourense y O Ribero y próximo a la frontera con Portugal. Nos encontramos la referencia a la aparición de dos cuerpos de hombres adultos en la orilla del río, se supone que habrian sido arrastrados por la corriente desde las proximidades. Ambos cuerpos levantados por la autoridad competente habrian sido enterrados por el vecindario bajo las escaleras que dan acceso al cementerio desde el atrio de la iglesia; también allí se encontraron los restos de un tercer cuerpo sin identificar.
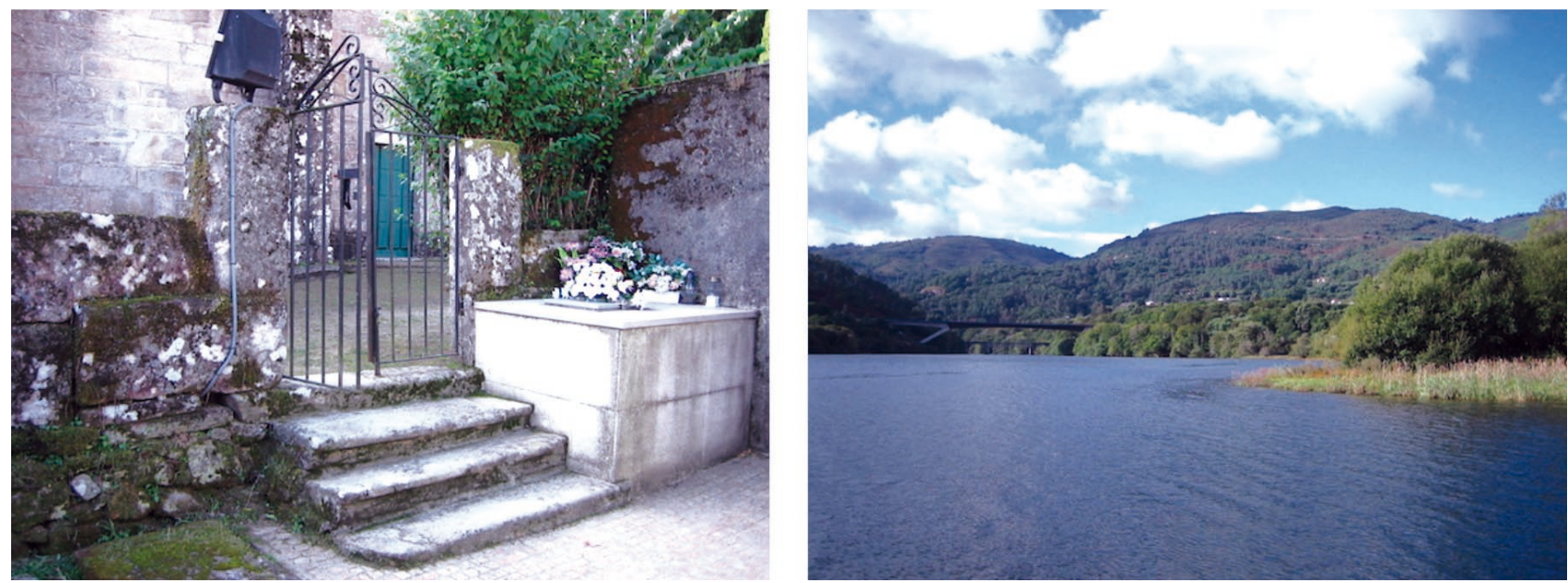

Imágenes 4 y 5

Vista del cementerio y de la orilla del río hacia Filgueira

(fotografías del autor)

Visito el río y el cementerio. La orilla del río no es accesible más que abriéndose camino entre la maleza y los árboles, toda una franja de vegetación espesa que se extiende a lo largo de la orilla (imagen 5). Las obras de la presa de Frieira (finalizada en 1970) han hecho subir el cauce del río (que difiere sustancialmente del de los años 30), y la franja de tierra inmediata es propiedad de la autoridad hidrográfica estatal. Lo que antes eran tierras de labor ahora es hogar de aves y animales acuáticos. Se ha perdido cualquier rastro de la cuenca original. Paralelo al río ya entonces discurría la línea de tren que unía Ourense con Vigo. La estación de tren (hoy en desuso) se encuentra en las inmediaciones del pequeño embarcadero que constituye el único acceso directo al agua. Entro en la zona de la estación y me detengo en el andén buscando cómo cruzar al lado del río. Un hombre (unos sesenta años) se dirige a mí y me comenta que ya no se puede pasar: "Antes se podía cruzar la vía y había un túnel para llegar 
a las fincas. Ahora está todo abandonado, también el tren" y me narra el proceso de declive de la estación, antes punto importante de carga de madera. La ribera era un lugar de trabajo, transitado y visitado al que llegaron dos cuerpos que no podían haber venido de muy lejos dado el bajo cauce del río en la época y los bancos de arena que se encuentran a pocos metros de la localidad. Esto les habrían impedido hacer un gran recorrido (imágenes 6 a 8 ).
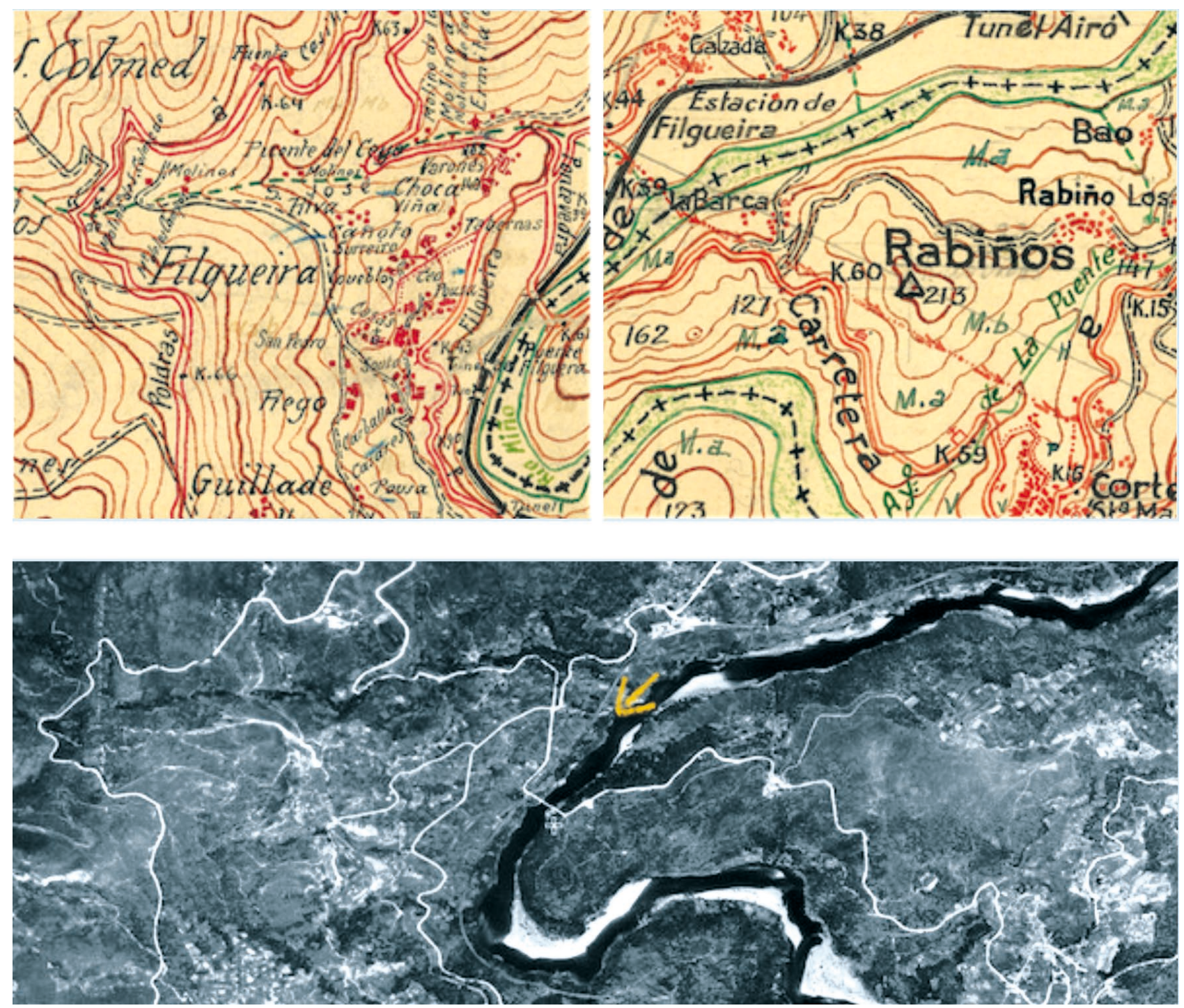

Imágenes 6, 7 y 8

Mapa histórico. Ortofoto ${ }^{10}$

A pocos kilómetros se encuentran la iglesia con el cementerio adosado. El atrio alberga el cementerio original, está enlosado de lápidas gastadas de granito que cubren gran parte de la superficie, lo que hace difícil (sino imposible) no pisar las tumbas para acceder al templo o al cementerio anejo. Las escaleras de piedra constituyen el único espacio marginal posible,

10 Accesible en: http://www.ign.es/web/comparador_pnoa/index.html\#map=16/-912579.21/5192852.08/0/5/ amsb. Última visita: 04/12/2019. 
tres escalones que une atrio y cementerio, más allá de los muros del recinto todo son tierras de cultivo. En la esquina inmediata al acceso, en el interior del cementerio, se ha construido un osario para restos. Sobre el osario hay flores y una figura religiosa que indican el carácter mortuorio del cubículo (imagen 4). No se escucha más que los pájaros y los ruidos de motores en la lejanía. Con un desplazamiento de menos de un metro los restos han pasado a formar parte plenamente del culto a los muertos, aún en su anonimato.

\subsection{Caso 3: Cuneta de Puga}

Ayuntamiento: Toén. Coord: 42.324688, -8.011062. Hoja: 225 (1942). Uso: Agrario (abandonados parcialmente en la actualidad).

Causa de muerte: paseo (1).

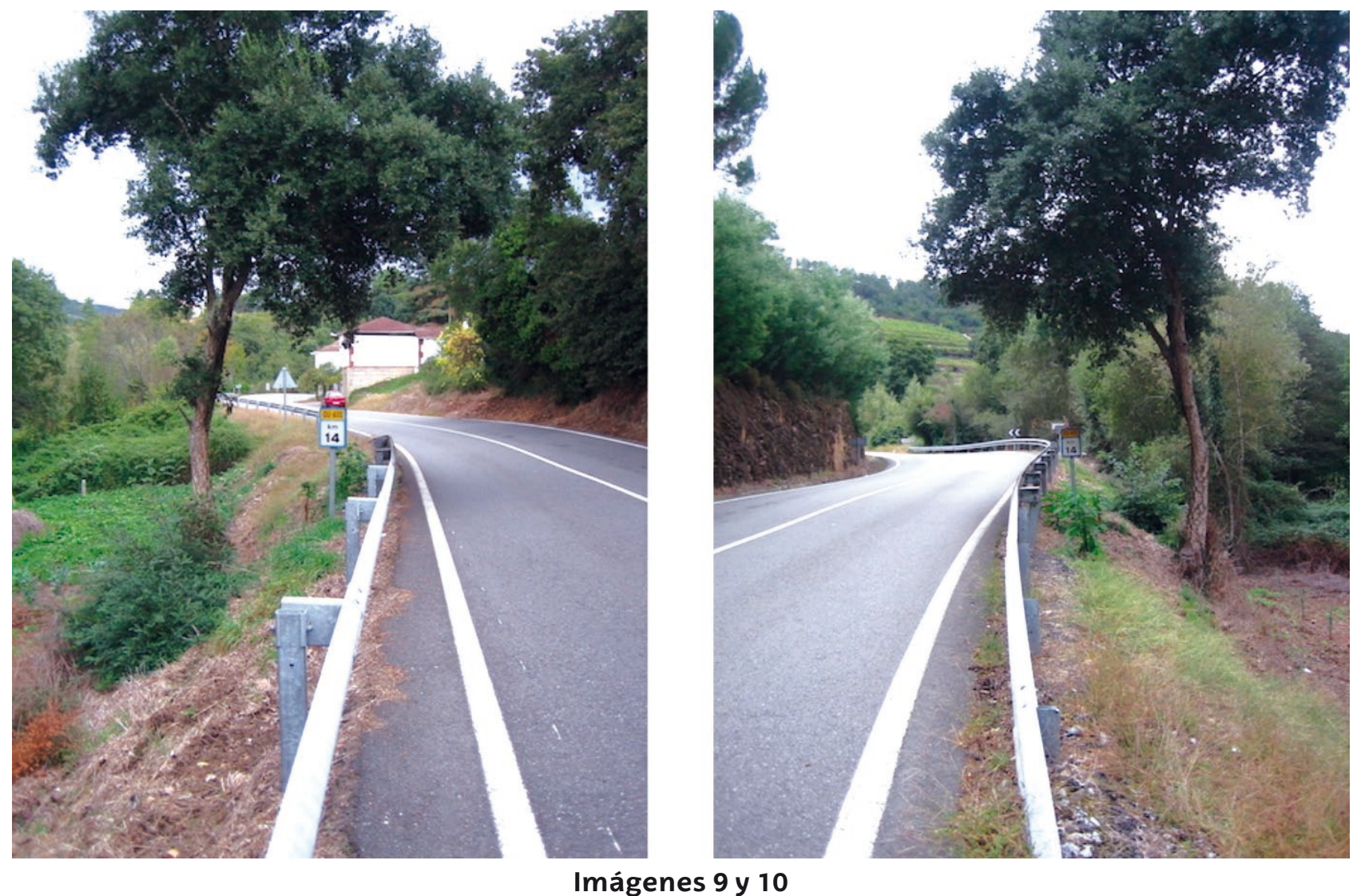

Vistas del kilómetro 14, dirección NO y SE

(fotografías del autor)

La ubicación está en el kilómetro 14 de la parroquia de Puga. Se trata de una vía central de comunicación en las afueras inmediatas del núcleo habitado. La actual carretera mantiene el trazado de la vía original que atraviesa tierras de cultivo y comunica la ciudad de Ourense con Castrelo de Miño y Ribadavia, en una zona de producción de vino. Hoy en día la vía soporta un tráfico local y es parte de una ruta apreciada por ciclistas. Un pequeño terraplén a ambos la- 
dos delimita la carretera de las fincas inmediatas, antaño una zona de cultivos que se extendía hasta el río. La orilla del río se encuentra a apenas 50 metros, se llega a ella a través de un antiguo camino que daba acceso a una pequeña instalación (un molino o una pesquería). Antes se trataba de un punto a medio camino entre dos pueblos, hoy es una de las muchas curvas del trayecto entre viñedos y cultivos. La única zona boscosa (pequeña) que se puede apreciar en la foto antigua (imagen 12) corresponde precisamente a este punto, un pequeño punto resguardado en las inmediaciones, sin la edificación aún que ahora apreciamos en la foto (imagen 9). Es un kilómetro cualquiera en una carretera cualquiera como otros muchos lugares de ejecución, fue lugar de tránsito obligado en su momento rodeado de tierras de labor, es decir, en medio de la vida cotidiana (imagen 10). Me acerco andando a los dos pueblos, nada relevante más que el trazado de la vía, y ese punto, en la mayor lejanía posible entre ellos.

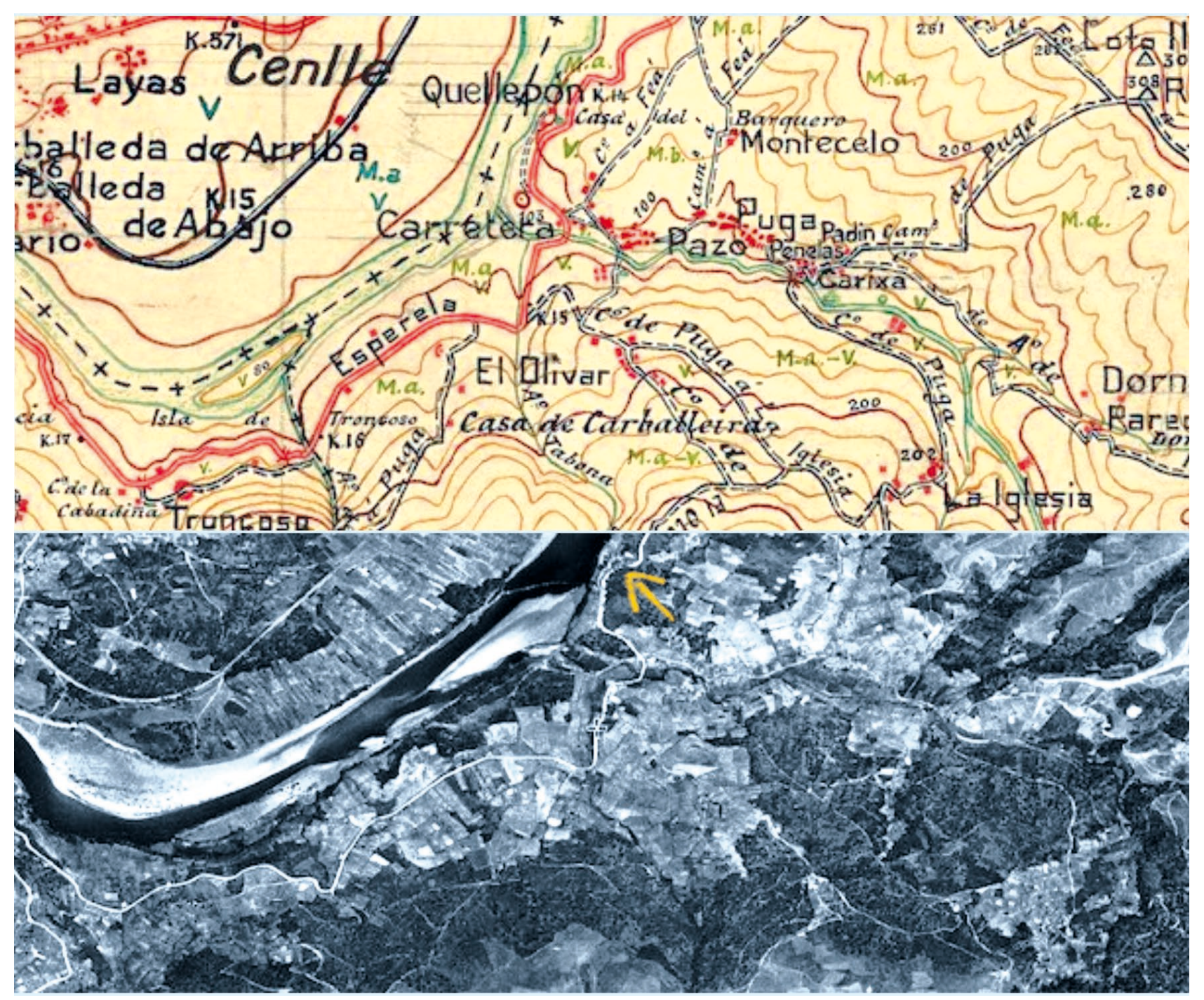

Imágenes 11 y 12

Mapa histórico. Ortofoto ${ }^{11}$

11 Accesible en: http://www.ign.es/web/comparador_pnoa/index.html\#map=16/-891795.65/5209701.99/0/5/ amsb. Última visita: 04/12/2019. 


\subsection{Caso 4: Monteferro}

Ayuntamiento: Nigrán. Coord.: 42.153785, -8.844308. Hoja: 261 (1940). Uso: Agrario (monte comunal, producción maderera y uso de ocio en la actualidad).

Causa de muerte: paseo (1).

Entre las playas de A Madorra y América, de un lado, y de Patos, del otro -lugares de veraneo y residencia muy apreciado en la actualidad-, se alza un pico, Monteferro. Destaca en la costa, es una cuña boscosa hacia un mar abierto y una costa abrupta (imagen13). Más allá, América. Está coronado por el monumento a la Marina Universal o a los Mártires del Mar (de 1924), una construcción modernista en forma de pirámide truncada con una altura de 25 metros de alto que se erige frente al Atlántico. Se trata de una zona frecuentada por visitantes dada la singularidad del lugar, es un mirador abierto al mar en tres direcciones. Merodeando por el lugar uno se encuentra con quienes aprovechan la zona habilitada para meriendas, los caminos entre los árboles, el aparcamiento y las vistas. Es la única zona sin viviendas en las proximidades en toda la franja costera inmediata. El lugar documentado se sitúa de forma imprecisa a unos 200 metros al oeste del monumento (imagen 14).
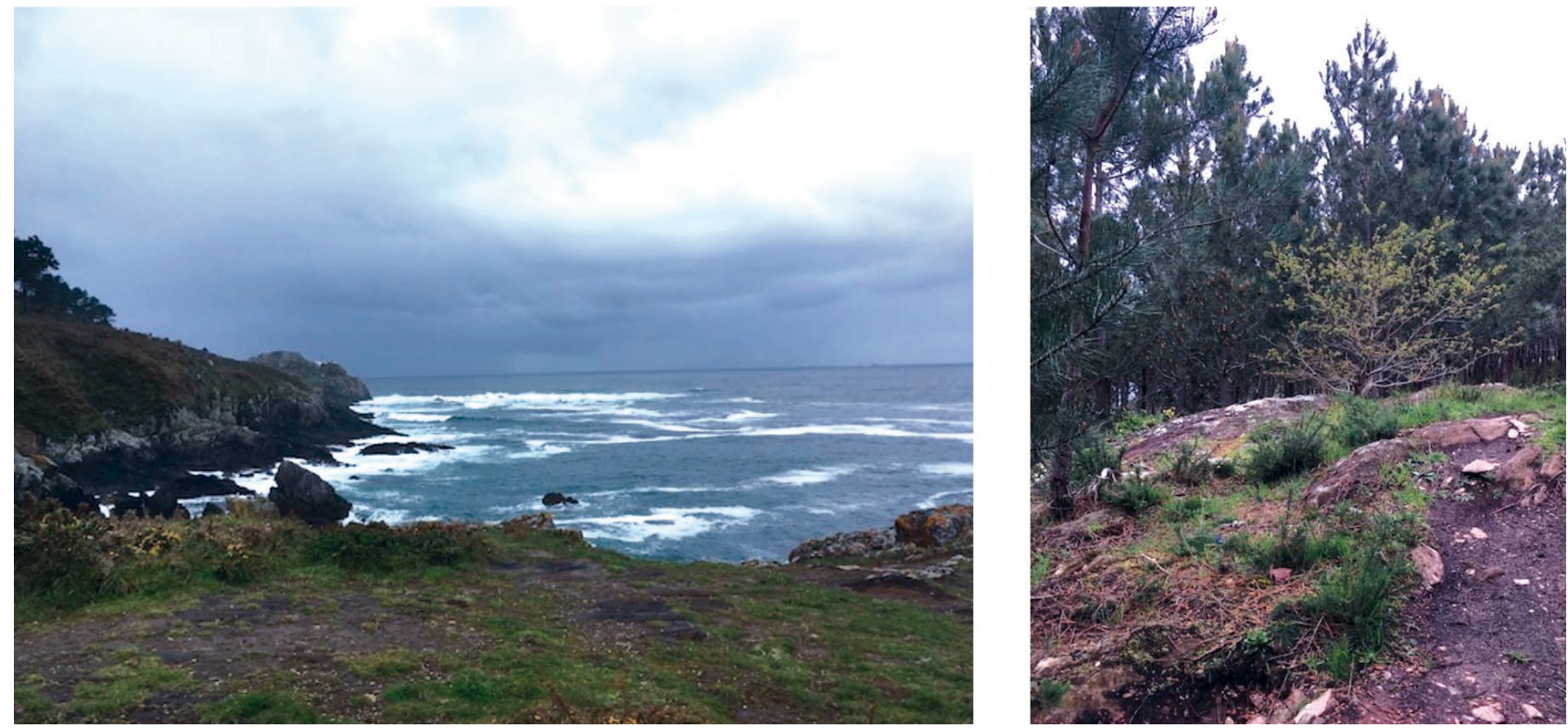

Imágenes 13 y 14

Vistas de la costa y a 200 metros Oeste del monumento

(fotografías del autor)

Descendiendo hacia el mar se llega a un camino que nos acerca hasta un pequeño faro en el extremo más occidental y abierto al mar; tres estudiantes fuman y charlan sentados en las rocas, y la costa se salpica con pescadores de caña. El mar bate contra los acantilados, trepo por las rocas y pienso en qué pasaría si me cayese ahora. Me extraña que en un lugar de costa tras una ejecución no se opte por arrojar el cuerpo al mar o a un acantilado, sino que se deje fuera de los límites del núcleo de población más próxima (Panxón), allí en donde acababa la carretera para el paseo. Entre el monumento y el faro quedan los restos de los cañones y las instalaciones de la guarnición militar emplazadas en septiembre de 1936. Todo en estado de avan- 
zado abandono. En la actualidad la zona, además de ser un lugar de esparcimiento, forma parte de una zona natural protegida que aspira a incorporarse al Parque nacional marítimo terrestre de las Islas Atlánticas. De ahí que encontremos paneles informativos sobre los valores naturales, y sobre restos arqueológicos neolíticos (petroglifos). La historia es la del pasado arqueológico no conflictivo y el paisaje el de la naturaleza neutra. No nos encontramos con ninguna referencia al lugar de ejecución ni siquiera a los restos de las instalaciones militares, se borra toda huella de conflicto humano. Nadie se dirige a 200 metros al Oeste, de espaldas al mar, una zona de monte sin interés. Ciertamente constituye la zona menos pintoresca.
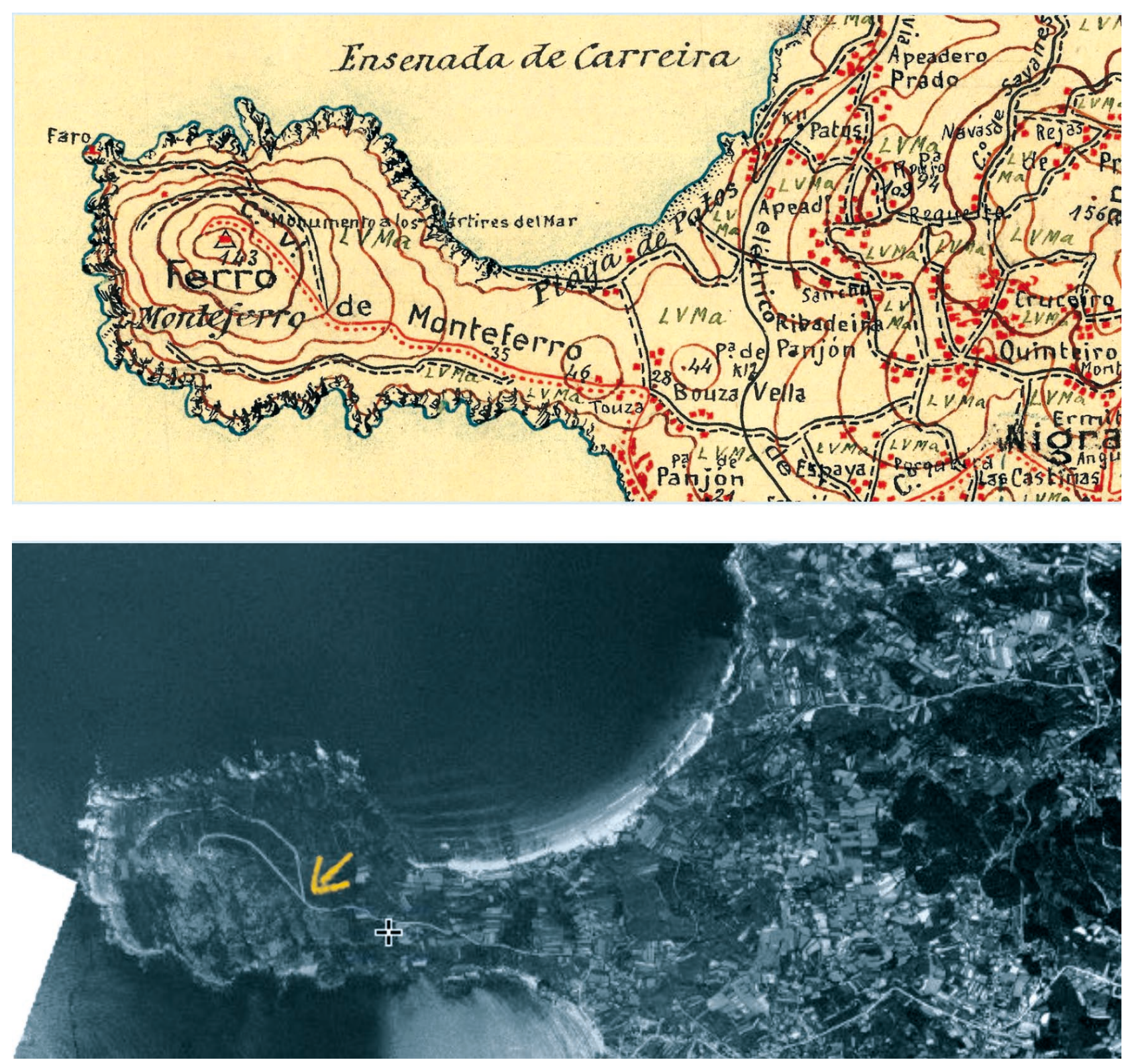

Imágenes 15 y 16

Mapa histórico. Ortofoto ${ }^{12}$

12 Accesible en: http://www.ign.es/web/comparador_pnoa/index.html\#map=15/-984295.18/5184006.54/0/0/ amsb. Última visita: 04/12/2019. 


\subsection{Caso 5: Monte de O Castro}

Ayuntamiento: Vigo. Coord: 42.23135, -8.72649. Hoja: 223 (1942). Uso: Hasta 1964 fortaleza defensiva con diferentes usos militares, de ocio en la actualidad.

Causa de muerte: no especificada (3), ejecución (32).

El Monte de O Castro es una elevación de 149 metros en el centro de la ciudad de Vigo, un parque de tipología inglesa de unas 21 hectáreas. Su cumbre está coronada por el Castillo (realmente una fortaleza que acogió una guarnición militar). La historia de la ciudad está marcada y articulada por él ya desde el siglo III a.C.

La actual fortaleza del siglo xvı mantuvo su carácter militar hasta 1964, pero el entorno se fusionaba ya con la vida civil. En los años 30 el parque suponía un límite entre la parte más densamente edificada de la ciudad (orientada hacia el puerto) y los barrios de estructura más rural orientados hacia el interior. En 1934 pasaron los terrenos colindantes a propiedad de la ciudad, siendo usados para actividades festivas y de ocio popular (romerías...), treinta años después también la fortaleza pasará a propiedad municipal y dará lugar al actual parque tras sucesivas intervenciones que lo convertirán en uno de los pulmones verdes de la ciudad. Hoy la ciudad se ha desarrollado a su alrededor, pasando a estar enclavado en su centro y próximo al ayuntamiento nuevo (de 1976). En su ladera una cruz de 12 metros de altura (de 1961) que se alza hacia el consistorio, concebida por sus promotores como Monumento a los Caídos por Dios y España. Desde los años 80 se ha iniciado una controversia pública sobre su derribo y sucesivas sentencias judiciales. En la actualidad se ha eliminado los elementos simbólicos claramente franquistas, pero tanto la cruz como la controversia persisten.

En el momento de la Guerra Civil la fortaleza está activa como instalación militar pero su uso es limitado. Pasará a ocupar las funciones de recinto de reclusión por parte del bando sublevado, y será lugar de juicios militares. Nomes e Voces (2016) recoge en su sección cartográfica 3 muertes por paseo, en su base de datos documenta 35 muertes (4 ejecuciones en el monte, 19 en las inmediaciones y 9 en la propia fortaleza); 3 cadáveres encontrados en el monte (no se indica el lugar de ejecución). En el momento de la sublevación supone -al igual que Monteferro- un espacio indeterminado, este está dentro de la estructura de la ciudad a caballo entre el centro urbano y los barrios de tipo rural, una isla destacada en las inmediaciones de su mismo centro, en esa tensión entre proximidad y marginalidad en el tejido urbano.

El bastión acoge ahora una zona ajardinada de acceso libre, accediendo a pie entramos en el primer muro de la fortaleza, y a la entrada del segundo en el lado izquierdo un monolito recuerda a las víctimas del franquismo (imágenes 17 y 18). Inaugurado en 2010, por la Asociación Viguesa pola Memoria Histórica do 36, hace constar 136 muertes como nos indica la inscripción: «Lugar de memoria. A los 136 hombres asesinados en este lugar por el franquismo entre 1936 y 1942 por defender la libertad. El pueblo no olvida. Vigo 16 de octubre 2010" ${ }^{13}$. En palabras de la secretaria de la asociación Amalia Collazo en el día de ser descubierto: «Estas piedras, que estuvieron hasta ahora calladas, por fin van a hablar» (Faro de Vigo 2010). Sobre el desajuste de números se aducen otras fuentes testimoniales. Al otro lado de la puerta hay

13 Original en gallego, traducción propia. 
una segunda estatua "Mujer pensando en sus cosas» (de 1996), con la cabeza apoyada en ambas manos; hoy parece penar por estos muertos. Habrá que rastrear si no fue la intención originaria del autor ${ }^{14}$.
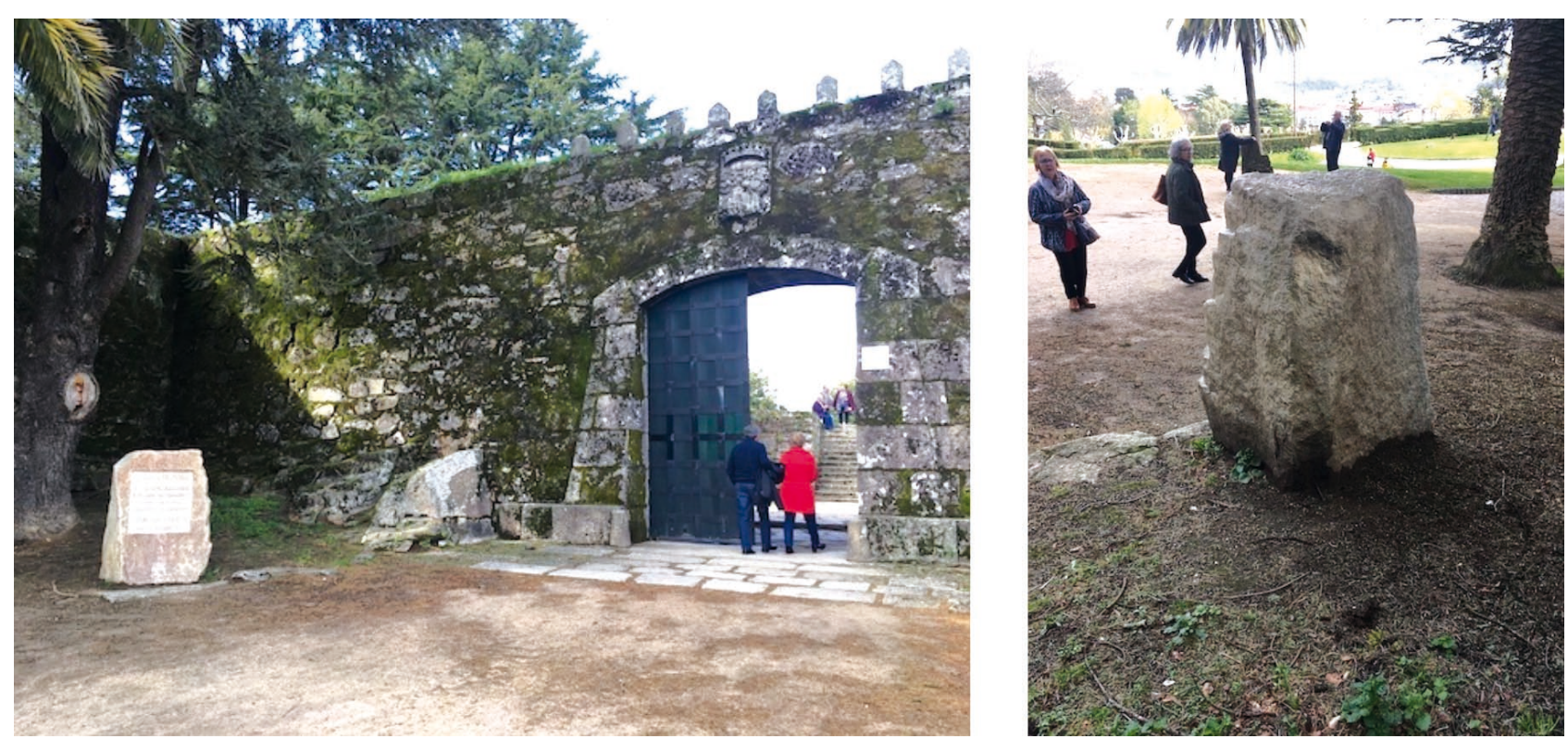

Imágenes 17 y 18

Vistas hacia y desde la entrada con monolito memorialístico

(fotografías del autor)

Nos encontramos aquí en un lugar frecuentado por turistas y visitantes en paseos vespertinos o durante el fin de semana. Me siento en las inmediaciones una mañana de domingo al otro lado de la entrada. Algunas personas y grupos se detienen y leen el texto en voz alta y continúan. Ahora la hija (unos once años) de un matrimonio lee el texto y pregunta qué es eso: "Aquí mataron a 136 personas..." dice la madre; "En la guerra» apostilla el padre, "¡Ah, yo pensaba que era ahora!» añade la hija, y continúan.

El ulular de las palomas posadas en las proximidades se mezcla con el ruido de los pasos que se alejan y adentran tras las murallas.

14 Silvino Silva Novas (1936-2001) fue un escultor local conocido por sus esculturas en piedra al aire libre. 

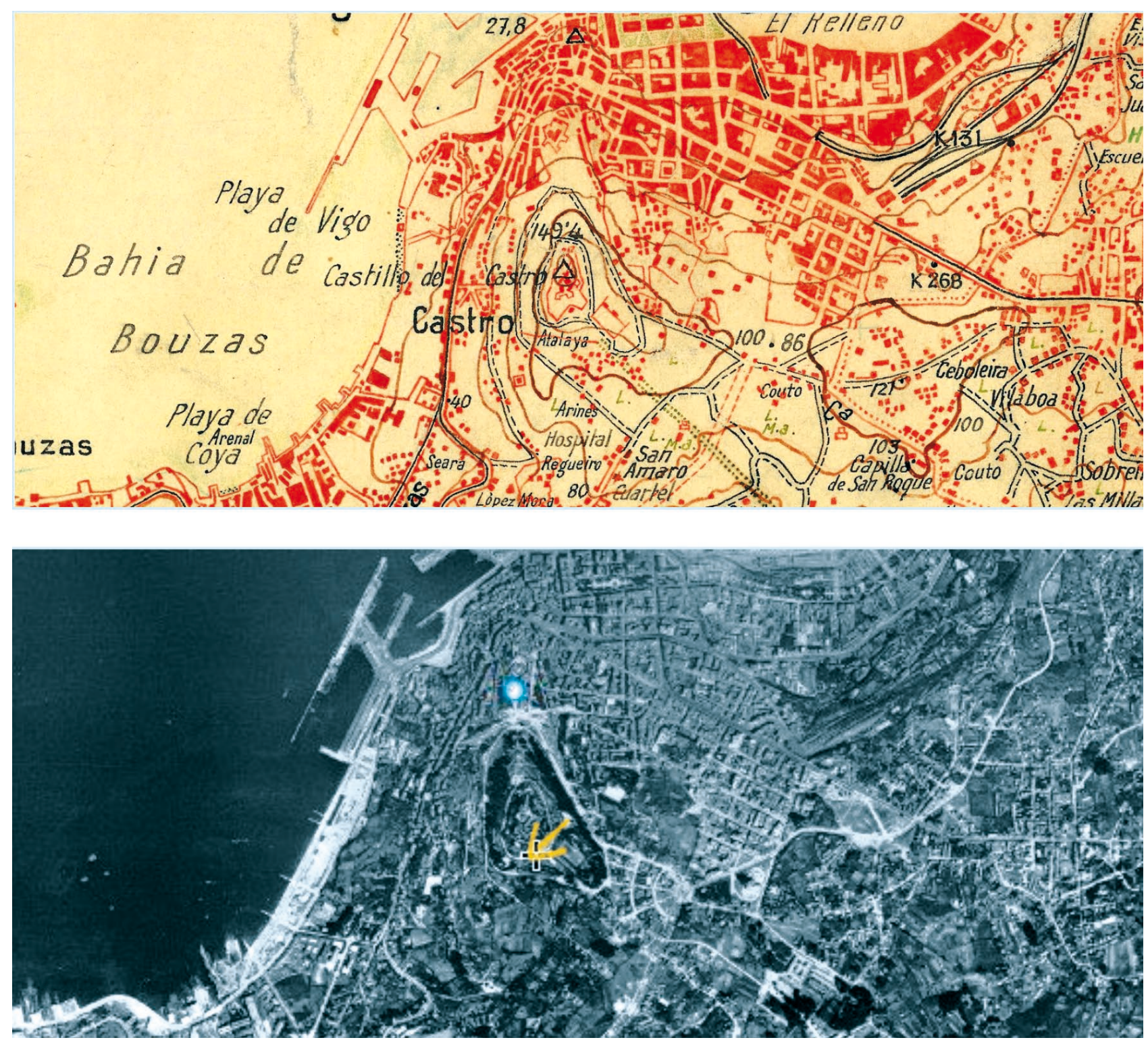

Imágenes 19 y 20

Mapa histórico. Ortofoto ${ }^{15}$

\section{CONCLUSIONES. EN EL ESPACIO HAY CASUÍSTICA Y NO CASUALIDAD}

No nos encontramos aquí los lugares en los que sistemáticamente y de forma continuada se procedía a la desaparición de cuerpos, como en el caso colombiano (botaderos), argentino (Río de la Plata) o chileno (costa del Pacífico). En el caso de la Guerra Civil española los lugares exactos de los enterramientos y ejecuciones no permanecen en los archivos públicos a pesar

15 Accesible en: http://www.ign.es/web/comparador_pnoa/index.html\#map=16/-971360.68/5195631.53/0/5/ amsb. Última visita: 04/12/2019. 
del levantamiento oficial de los cadáveres y la orden de que los cuerpos sean enterrados en el cementerio más cercano pero sí en la memoria de muchas personas, que cada vez son menos (Bolaños, 2010). Por las condiciones del terreno hubiese sido posible llevar a cabo las ejecuciones en lugares escondidos o de difícil acceso. La indefinición de las localizaciones no contradice, mas avala, ese interés por generar un sentimiento de amenaza perturbador; los hechos son claros. Estos lugares han de ser necesariamente anodinos y carentes de atributos que permitan la memoria, el duelo o la reivindicación. Como resultado de esta metodología peripátética se ha llegado física y conceptualmente a los infraloci, ahí en donde apenas hay indicios nos hemos detenido en esa ausencia de pruebas y hemos indagado otras posibilidades de acercamiento. Infraloci que son lugares, más que instalaciones creadas o apropiadas específicamente como instrumentos para generar sufrimiento, dolor y muerte. De ahí que su carga simbólica y significado vayan más allá de la maquinaria de matar, ya que se inscriben en el terror de lo inmediato, lo cotidiano, en los márgenes de la vida común. Quedan inscritos en el espacio de forma sorda, persistente - como advertencia - o inadvertida - como rastro de la insignificancia de quien está ahí-. Y su valor político actual radica precisamente en mantener la incertidumbre del quién, en dónde y cómo.

Las fosas comunes se caracterizan por ser una prueba de la dimensión de la represión política más allá de los enfrentamientos armados entre los dos bandos pero que se responden a acciones de guerra. Y aunque no nos enfrentemos a grandes enterramientos colectivos, sí se pueden entender como tales aunque en muchos casos se trate de enterramientos individuales. Suponen una fosa común extendida a lo largo de un vasto territorio, no es un único emplazamiento en el que se concentre el horror. Responden más a la estructura -cartografiable- de una red y a una lógica de represión. Expresado de otra manera, son fosas comunes extensas y dispersas, compuestas de múltiples enterramientos enlazados. Son fosas comunes fragmentadas, o fosas de tela de araña, con un ejecutor común y víctimas geográficamente dispersas. Son el testimonio y la prueba de que la transición se ha realizado en base a un pacto de silencio, de aquiescencia con el relato oficial de la historia de la guerra fratricida en la que "todos fueron culpables» (Izquierdo Martín, 2014: 59). Y, en definitiva, son centrales en la demanda de muchas personas que reclaman poder recuperar los restos de familiares, en gran medida para poderles tener uun entierro digno que le diferencie del de los perros y alimañas» (Ferrándiz, 2009: 87).

La represión habría de ser visible pero no pública, tampoco clandestina ni subterránea. Su función estriba en poder ser presente, aunque no mostrada, poder deslegitimar al adversario en su propia humanidad, aniquilando su valor social, político y moral, reduciéndolo a un resto donde los argumentos e ideales muestran su inutilidad. De ahí su carácter aleccionador, de la "pedagogía de la sangre» (Rodrigo, 2008: 73). Los juicios sumarísimos, la ley de fugas, los paseos, encarcelamientos, robos de bebés, violaciones y palizas, apropiaciones de bienes, y depuraciones serán todas ellas prácticas destinadas a generar un clima de vulnerabilidad entre el conjunto de la población. Lo que me interesa es cómo estas prácticas, en concreto las de muerte extranormativa y extrajudicial, se inscriben en el terreno de acuerdo a una lógica de la infrahumanización.

Las prácticas de desaparición niegan la humanidad de quien ha sido ajusticiado, los restos yacen en lugares y en formas que no son los que les corresponderían a quienes sí son considerados como personas. Los infralocus no son simplemente el escenario de una muerte violenta, son paisajes del terror, lugares marginales que marcan a quien es allí muerto, no como un acto casual (pasó allí), sino que son parte de una estrategia específica (allí pasó), que hace 
que el lugar sea también relevante. Contagia simbólicamente el cadáver, que ha de ser reconocido como de ínfimo valor, como una forma de construir infrahumanidad. Y nos anuncia cuál es su valor verdadero. De la misma manera que la resistencia y negativa de responsable políticos a la tarea de localización de fosas y excavación, sigue suponiendo una legitimación de las prácticas represivas llevadas a cabo anteriormente y reproducen la lógica de la infrahumanización.

\section{REFERENCIAS}

Agamben, G. (2011). Lo que queda de Auschwitz. Valencia: Pre-textos.

Anstett, É. (2017). Comparación no es razón: a propósito de la exportación de las nociones de desaparición forzada y detenidos-desaparecidos. En G. Gatti (Ed.). Desapariciones: usos locales, circulaciones globales (pp. 33-51). Bogotá: Siglo del Hombre Editores, Universidad de los Andes.

Albo, F. (2018, 9 de enero). La cueva de Arcoia, en peligro por las visitas incontroladas. La Voz de Galicia. Disponible en: https://www.lavozdegalicia.es/noticia/lemos/2018/01/09/ cueva-arcoia-peligro-visitas-incontroladas/0003_201801M9C12991.htm

Aventuras de Galicia (2019). Espeleología Cueva Arcoia. A Seara. Serra do Courel (Lugo) Galicia. Disponible en: https://www.aventurasengalicia.com/aventuras_en_galicia_ actividades.php?aventurasID=4068titulo=Espeleolog\%C3\%ADa\%20Cueva\%20 Arcoia.\%20A\%20Seara.\%20Serra\%20do\%20Courel\%20(Lugo)\%20Galicia\&localidad= Courel\&provincia=Lugo

Benjamin, W. (1993). Baudelaire: poesía y capitalismo. Barcelona: Taurus.

Bolaños, A. (2010). La Ley de memoria histórica y la búsqueda de los desaparecidos en España: una aproximación desde la arqueología forense. Arqueología y Sociedad, 22, 73-82.

Burucúa, J.E., y Kwiatkowski, N. (2014). «Cómo sucedieron estas cosas»: representar masacres y genocidios. Buenos Aires, Madrid: Katz.

Butler, J. (2006). Vida precaria: El poder del duelo y la violencia. Barcelona: Paidós.

Calveiro, P. (1998). Poder y desaparición: Los campos de concentración en Argentina. Buenos Aires: Colihue.

Careri, F. (2014). El andar como práctica estética. Barcelona, Naupalcan: Editorial Gustavo Gili.

Careri, F. (2016). Pasear, detenerse. Barcelona: Editorial Gustavo Gili.

Casado-Neira, D., Castillejo-Cuéllar, A., Díaz, P., y Ruiz-Estramil, I. B. (2019). Materializando la desaparición: la singularidad de sus cosas. Oñati Socio-legal Series [online], 9(2), 237251. Disponible en: https://doi.org/10.35295/osls.iisl/0000-0000-0000-1025

Castoriadis, C. (1975). La institución imaginaria de la sociedad. Barcelona: Tusquets Editores.

CNIG (Centro Nacional de Información Geográfica) (2019). Centro Nacional de Información Geográfica. Disponible en: http://centrodedescargas.cnig.es/CentroDescargas/ buscadorCatalogo.do 
Estatuto de Galicia de 1936 Que a Asemblea Rexional de Concellos celebrada en Santiago de Compostela durante os días 17, 18 e 19 de decembro de 1932, acordou propoñer á votación dos electores, conforme ó artigo 12 da Constitución. Disponible en: https:// upload.wikimedia.org/wikipedia/commons/c/c4/Estatuto_de_Galicia_de_1936\%2C_ pdf_texto_gl.pdf

Etxeberria, F., Serrulla, F., y Herrasti, L. (2014). Simas, cavernas y pozos para ocultar cadáveres en la Guerra Civil española (1936-1939). Munibe Antropologia-Arkeologia, 65, 269-288.

Faro de Vigo (2010, 17 de octubre). Memoria tallada en piedra. Faro de Vigo. Disponible en: http://www.farodevigo.es/gran-vigo/2010/10/17/memoria-tallada-piedra/482027.html

Ferrándiz, F. (2009). Fosas comunes, paisajes del terror. Revista de Dialectología y Tradiciones Populares, 64(1), 61-94. Disponible en: https://doi.org/10.3989/rdtp.2009.029

Ferrándiz, F. (2011). Autopsia social de un subtierro. Isegoria, 45, 525-544. Disponible en: http:// isegoria.revistas.csic.es/index.php/isegoria/article/viewFile/741/739

Gatti, G. (2008). El detenido-desaparecido. Narrativas posibles para una catástrofe de la identidad. Montevideo: Ediciones Trilce.

Gatti, G., Martínez, M., y Peñaranda-Cólera, M. del C. (2019). La «técnica» de la desaparición. Oñati Socio-legal Series [online], 9(2), 252-266. Disponible en: https://doi.org/10.35295/ osls.iisl/0000-0000-0000-1026

Gómez Bravo, G. (2017). Geografía humana de la represión franquista: Del golpe a la guerra de ocupación (1936-1941). Madrid: Cátedra.

Humboldt, A. von (2004). Ansichten der Natur: mit wissenschaftlichen Erläuterungen und sechs Farbtafeln, nach Skizzen des Autors. Frankfurt en el Meno: Eichborn.

IGN y CNIG (Instituto Geográfico Nacional y Centro Nacional de Información Geográfica) (2019). Comparador de ortofotos PNOA. Disponible en: http://www.ign.es/web/ comparador_pnoa/index.html

Izquierdo Martín, J. (2014). Que los muertos entierren a sus muertos. Narrativa redentora y subjetividad en la España postfranquista. Pandora, 12, 43-63.

James, R. C., y James, G. (1992). Mathematics Dictionary. Nueva York: Chapman and Hall.

Juana López, J. de, Rodríguez Teijeiro, D., y Prada Rodríguez, J. (2005). Campos de concentración y sistema penitenciario en Galicia durante la Guerra Civil. En Homenaxe á profesora Lola A. ferro. Estudios de historia, arte e xeografía (pp. 279-299). Vigo: Universidade de Vigo.

Lubrich, O., y Möhl, A. (2019). Botanik in Bewegung Alexander von Humboldt und die Wissenschaft der Pflanzen. Berna: Haupt Verlag.

Martínez, M., Robles Elong, I., y Ruiz-Estramil, I. B. (2019). Más allá de los tópicos en el estudio de la desaparición. Hacia el desaparecido social. Oñati Socio-legal Series [online], 9(2), 169-182. Disponible en: https://doi.org/10.35295/osls.iisl/0000-0000-0000-1020

Nogué, J. (2015). Emoción, lugar y paisaje. En T. Luna e I. Valverde (Dirs.). Paisaje y emoción. El resurgir de las geografías emocionales (pp. 137-148). Barcelona: Observatorio del Paisaje de Cataluña y Universitat Pompeu Fabra. 
Nomes e Voces (2016). Nomes e voces. Proxecto interuniversitario. Disponible en: http://www. nomesevoces.net

Pallasmaa, J. (2014). Los ojos de la piel: la arquitectura y los sentidos. Barcelona: Editorial Gustavo Gili.

Prada Rodríguez, J. (2006). Rebelión militar y represión franquista en Galicia. Studia Historica. Historia Contemporánea, 24, 153-177.

Prada Rodríguez, J. (2011). Geografía de la represión franquista en Galicia. Madrid: Catarata.

Prada Rodríguez, J. (Dir.). (2014). No solo represión. Madrid: Biblioteca Nueva.

Preston, P. (2011). El holocausto español. Odio y exterminio en la Guerra Civil y después. Barcelona: Debate.

Rodrigo, J. (2008). Hasta la raíz: violencia durante la Guerra Civil y la dictadura franquista. Madrid: Alianza Editorial.

Sanguin, A.-L. (1981). La géographie humaniste ou l'approche phénoménologique des lieux, des paysages et des espaces. Annales de géographie Année, 501, 560-587.

Schindel, E., y Colombo, P. (Eds.). (2014). Space and the memories of violence: landscapes of erasure, disappearance and exception. Houndmills, Basingstoke, Hampshire, Nueva York: Palgrave Macmillan.

Sturdy Colls, C. (2015). Physical Evidence of the Holocaust. En Holocaust Archaeologies (pp. 199-233). Cham: Springer.

Vallejo-Nájera, A. (1936). Psicopatología de la Conducta Antisocial. Acción Española, 83, 169194. Disponible en: http://hemerotecadigital.bne.es/issue.vm?id=00037051028search =\&lang=en

Vallejo-Nájera, A. (1938). Política Racial del Nuevo Estado. San Sebastián: Editorial Española. Disponible en: http://www.ub.edu/fildt/revista/rbyd26_art-capuano-carli.htm\#_ftn25

van Gennep, A. (2008). Los ritos de paso. Madrid: Alianza Editorial.

Walser, R. (2001). El paseo. Madrid: Siruela.

Wieviorka, A. (1998). L'ère du témoin. París: Plon. 